\title{
Treatment of Recurrent Glioblastoma Multiforme (rGBM) with Antineoplaston AS2-1 in Combination with Targeted Therapy
}

\author{
Stanislaw R. Burzynski ${ }^{1}$, Tomasz Janicki ${ }^{1}$ \& Samuel Beenken ${ }^{2}$ \\ ${ }^{1}$ Burzynski Clinic, Houston, TX, USA \\ ${ }^{2}$ Calera, AL, USA \\ Correspondence: Stanislaw R. Burzynski, Burzynski Clinic, Houston, TX, USA. Tel: 713-335-5697. E-mail: \\ srb@burzynskiclinic.com
}

Received: December 21, 2018 Accepted: January 10, $2019 \quad$ Online Published: January 29, 2019

doi:10.5539/cco.v8n1p1

URL: https://doi.org/10.5539/cco.v8n1p1

\begin{abstract}
Treatment of recurrent glioblastoma multiforme (rGBM) poses a difficult challenge. Therefore, the purpose of this report was to evaluate objective response (OR), progression-free survival (PFS), overall survival (OS), and the incidence of adverse events (AEs) in rGBM patients, age 19-70 years, who were treated with antineoplaston AS2-1 (Astugenal) plus targeted therapy. A retrospective analysis was performed. Tumor response was assessed by gadolinium-enhanced magnetic resonance imaging (MRI). Twenty-nine adult rGBM patients were treated between $9 / 11 / 2015$ and $06 / 23 / 2018$. Seven had no prior treatment with bevacizumab elsewhere, had radiologic evidence of rGBM, and had MRI assessment of tumor response. The median treatment time was 101 days (range: 55-208 days). OR was seen in six patients (85.7\%) with complete disappearance of gadolinium enhancement in four patients $(57.1 \%)$ and a $50 \%$ or greater reduction in gadolinium enhancement in two patients (28.6\%). Progressive disease was seen in one patient (14.3\%). The median time to first response was 29 days (range: 22-96 days) while the median duration of response was 141 days (range 55-739+ days). Six- and 12-month PFS was 57\% and 19\%, respectively while 6- and 12-month OS at was $86 \%$ and 54\%, respectively. Treatment was well-tolerated with no patients experiencing grade 3 or 4 antineoplaston-related toxicity. Regarding response to treatment and toxicity, AS2-1 plus targeted therapy compares favorably with other reported rGBM therapies. Duration of response was shortened by the ill-advised decision of some patients to discontinue treatment after a tumor response was achieved.
\end{abstract}

Keywords: antineoplaston AS2-1, Astugenal, recurrent glioblastoma, survival in recurrent glioblastoma, targeted therapy

\section{Introduction}

Glioblastoma multiforme (GBM) is the most common and most aggressive primary malignant brain tumor (Ostrom et al., 2018). The prognosis for newly-diagnosed GBM patients is poor with a median survival of 14.6 months from diagnosis despite standard treatment with surgery, radiation therapy (RT), adjuvant temozolomide (TMZ) and bevacizumab (BVZ) (Stupp et al., 2005; Ohka, Natsume \& Wakabayashi, 2012). After standard therapy, the 5-year overall survival (OS) rate is in the range of 1\% - 2\% (Olson et al., 2014; Stupp et al., 2005) while median progression-free survival (PFS) is 6 to 9 months (Stupp et al., 2009). The prognosis for patients with recurrent GBM (rGBM) is much worse, with most patients dying within six months of recurrence.

In phase II clinical trials (IND 43742), we have evaluated treatment of GBM and rGBM with antineoplastons, a group of peptides, amino acid derivatives, and carboxylic acids that inhibit the growth of neoplastic cells without inhibition of the growth of normal cells (Burzynski, 1976; Burzynski, 1986; Burzynski, 2004; Burzynski, 2006; SR Burzynski, Janicki, GS Burzynski \& Marszalek, 2014, 2051-2061; SR Burzynski, Janicki, GS Burzynski \& Marszalek, 2014, 565-577; SR Burzynski, Janicki \& GS Burzynski, 2014; SR Burzynski, Janicki, GS Burzynski, Marszalek \& Brookman, 2014; SR Burzynski, GS Burzynski \& Janicki, 2014).

Phase II studies, utilizing antineoplastons AS2-1 (Astugenal) and A10 (Atengenal) in combination, evaluated their safety and efficacy in recurrent high-grade glioma, with a special emphasis on rGBM. Objective responses (ORs) were achieved in $17 \%$ of eligible patients while overall survival (OS) was $65.5 \%$ at six months, $56.7 \%$ at nine months, $39 \%$ at one year, and $4.4 \%$ at two, five, and ten years (SR Burzynski, Janicki \& GS Burzynski, 2014). 
AS2-1 is composed of phenylacetylglutaminate (PG) and phenylacetate (PN) and together with its metabolites affects approximately 100 abnormal genes in the GBM genome (Burzynski \& Patil, 2014). Published data indicate that some GBM patients will respond to antineoplastons alone but for most GBM patients antineoplastons will not be effective in controlling approximately 650 abnormal genes in the GBM genome. Therefore, we elected to treat these terminal rGBM patients with a combination of AS2-1 plus targeted therapy that was based on genomic profiling. We report here on seven evaluable patients with rGBM treated with AS2-1 and targeted therapy. Three of these patients also received A10.

\section{Patients and Methods}

\subsection{Patients}

Between 9/11/2015 and 06/23/2018, 29 adult GBM patients age 19-70 years received treatment at the Burzynski Clinic (BC) under the state's "Right to Try" law. Of these 29 patients, 18 had not received standard of care treatment, had received prior treatment elsewhere with BVZ, and/or did not have radiologic evidence of recurrence. Of the remaining 11 patients, only seven had follow-up magnetic resonance imaging (MRI) for evaluation of tumor response. These seven patients received AS2-1 and, based on genomic testing, also received targeted therapies that were given sequentially over a period of days as determined by the characteristics of the individual targeted therapies. These seven patients are the focus of this report.

Data were collected by retrospective medical record review. Table 1 shows the patients' pathology, treatment, and recurrence data (as reported from outside institutions) prior to treatment with AS2-1 plus targeted therapy at BC. Cases \#2, \#6, and \#7 received sodium phenylbutyrate (PB) plus targeted therapy (including BVZ) at BC prior to receiving AS2-1 plus targeted therapy. However, their disease did not progress during prior BVZ therapy at BC.

Standard blood and urine analyses were performed at BC and at other institutions. Molecular profiling of tissue samples was performed by Foundation Medicine (FMI) of Cambridge, MA and Caris Life Science (CLS) of Phoenix, AZ, neither of which have any affiliation with BC. See Table 2.

All patients read, indicated their understanding of, and signed an informed consent document, which explained in detail the treatment and possible associated adverse events (AEs).

As described above, the treatment plan for any patient was based on genomic profiling and consisted of antineoplaston AS2-1 for broad-spectrum coverage and selected targeted agents for specific genomic abnormalities (SR Burzynski, GS Burzynski \& Janicki, 2014). 
Table 1. Pathology and prior treatment and recurrence data

\begin{tabular}{|c|c|c|c|c|}
\hline Case \# & $\begin{array}{l}\text { Pathology diagnosis } \\
\text { and date }\end{array}$ & $\begin{array}{l}\text { Treatment prior to AS2-1 } \\
\text { plus targeted therapy }\end{array}$ & $\begin{array}{l}\text { Recurrence } \\
\text { date }\end{array}$ & $\begin{array}{l}\text { Recurrence } \\
\text { assessment }\end{array}$ \\
\hline \multirow[t]{3}{*}{1} & GBM - 6/9/2015 & SU 6/1/2015 - Subtotal resection & & \\
\hline & & RT 6/24/2015-7/30/2015 60Gy & $9 / 1 / 2015$ & Recurrence \\
\hline & & TMZ 7/30/2015 - 7/30/2015 & & + new lesion \\
\hline \multirow[t]{7}{*}{2} & GBM - 11/14/2011 & SU 11/1/2011 - Total resection & & \\
\hline & & RT 12/12/2011-1/24/2012 & & \\
\hline & & TMZ 12/12/2011-1/24/2012 & & \\
\hline & & SU 2/25/2012 & & \\
\hline & & BC: 4/18/2012-10/21/2015 & & \\
\hline & & PB, erlotinib, BVZ, TMZ, sirolimus & $8 / 14 / 2015$ & New lesion \\
\hline & GBM - 9/17/2015 & SU 09/17/2015 - Total resection & $10 / 15 / 2015$ & Progression \\
\hline \multirow[t]{8}{*}{3} & GBM - 4/8/2014 & SU 4/8/2014 & & \\
\hline & & RT 4/30/2014-6/12/2014 60Gy & & \\
\hline & & TMZ 4/30/2014-7/8/2014 & $8 / 2014$ & Recurrence \\
\hline & GBM - 8/14/2014 & SU 8/14/2014 & & \\
\hline & & Aug 2014 Vaccination trial (UCLA) & & \\
\hline & & TMZ 10/1/2014 - April 2015 & $9 / 2015$ & Progression \\
\hline & & $\begin{array}{l}\text { September } 2015 \\
\text { pembrolizumab + nivolumab }\end{array}$ & & \\
\hline & & SU 1/18/2016, 6/12/2016; 10/2/2016 & $12 / 9 / 2016$ & Progression \\
\hline \multirow[t]{7}{*}{4} & Astrocytoma Grade IV & SU $1 / 5 / 2009$ & & \\
\hline & $(\mathrm{GBM})-1 / 5 / 2009$ & RT 2/16/2009-4/1/2009 59Gy & & \\
\hline & GBM - 1/4/2016 & TMZ 2/16/2009-4/4/2009 & $12 / 24 / 2015$ & New lesions \\
\hline & & SURG 1/4/2016 & & \\
\hline & & RT 2/2/2016-3/7/2016 59 Gy & & \\
\hline & & TMZ 2/2/2016-9/16/2016 & $12 / 12 / 2016$ & Recurrence \\
\hline & & RT 12/20/2016 (Gamma knife) & $1 / 2017$ & Progression \\
\hline \multirow[t]{4}{*}{5} & GBM - 10/3/2016 & SU 9/20/2016 - Total resection & $3 / 1 / 2017$ & Progression \\
\hline & & RT 10/2016 -11/30/2016 & & \\
\hline & & TMZ 10/2016 -11/30/2016 & & \\
\hline & & TMZ 01/2017 - 03/7/2017 & & \\
\hline \multirow[t]{5}{*}{6} & GBM - 6/8/2015 & SU 5/11/2015 - Total resection & & \\
\hline & & RT 6/1/2015-7/22/2015 60 Gy & & \\
\hline & & TMZ 6/1/2015-7/07/2016 & 2/8/2017 & Progression \\
\hline & & BC: 2/22/2017-7/10/2017 & & \\
\hline & & $\begin{array}{l}\text { PB, dasatinib, pazopanib, } \\
\text { everolimus, BVZ (5/26/2017) }\end{array}$ & $6 / 28 / 2017$ & Progression \\
\hline \multirow[t]{4}{*}{7} & $\begin{array}{l}\text { Diffuse glioma with } \\
\text { possible }\end{array}$ & $\begin{array}{l}\text { SU 8/12/2014 - Subtotal resection } \\
\text { SU 10/2/2015 }\end{array}$ & & \\
\hline & oligodendro-glioma & RT $11 / 12 / 2015-12 / 24 / 2015$ & $8 / 5 / 2015$ & Progression \\
\hline & component - 8/18/2014 & BC: 1/8/2016-5/20/2016 & & \\
\hline & GBM $-10 / 16 / 15$ & $\begin{array}{l}\text { PB, everolimus, dasatinib, } \\
\text { sorafenib, BVZ }\end{array}$ & $5 / 24 / 2016$ & Progression \\
\hline
\end{tabular}

Abbreviations: BC, Burzynski Clinic; BVZ, bevacizumab; GBM, glioblastoma multiforme; PB, sodium phenylbutyrate; RT, radiation therapy; SU, surgery; TMZ, temozolomide

Therapy was performed on an out-patient basis. Following an initial two to four week treatment period at BC, patients continued their treatment at home under our care and in cooperation with local oncologists. Prior to the start of treatment, an MRI with and without gadolinium-enhancement, was performed. For each measurable lesion (gadolinium enhancing and at least $5 \mathrm{~mm}$ in diameter) the product of the two largest perpendicular diameters was calculated and then the products of all measureable lesions were totaled (SUM), providing a baseline evaluation for each study subject and a reference for determining response to the treatment, which was assessed by MRIs performed every four to six weeks during initial treatment and every three months thereafter. 
Additional assessments included demographics, medical history, current medications, physical examination, vital signs, clinical disease status, and the Karnofsky Performance Status (KPS).

Table 2. Genomic testing, alterations identified, and GBM subtype

\begin{tabular}{|c|c|c|c|}
\hline Case \# & Institution & $\begin{array}{l}\text { Genomic alterations identified } \\
\text { (up to five alterations listed) }\end{array}$ & GBM subtype \\
\hline 1 & $\begin{array}{l}\text { Foundation Medicine } \\
\text { International } \\
\text { Cambridge, MA }\end{array}$ & $\begin{array}{l}\text { CDK4 amplification } \\
\text { KDR amplification } \\
\text { KIT amplification } \\
\text { PDGFRA amplification } \\
\text { PIK3CA amplification }\end{array}$ & Proneural \\
\hline 2 & $\begin{array}{l}\text { Caris Life Science } \\
\text { Phoenix, AZ }\end{array}$ & $\begin{array}{l}\text { PTEN amplification } \\
\text { EGFR low } \\
\text { MGMT negative } \\
\text { RRM1 negative } \\
\text { TS negative }\end{array}$ & Classical \\
\hline 3 & $\begin{array}{l}\text { Caris Life Science } \\
\text { Phoenix, AZ }\end{array}$ & $\begin{array}{l}\text { TOP2A positive } \\
\text { TOPO1 positive } \\
\text { TS positive }\end{array}$ & Classical \\
\hline 4 & Not performed & & IDH wild type \\
\hline 5 & $\begin{array}{l}\text { Foundation Medicine } \\
\text { International } \\
\text { Cambridge, MA }\end{array}$ & $\begin{array}{l}\text { AKT3 amplification } \\
\text { EGFR amplification } \\
\text { CDKN2A/B loss } \\
\text { SMARCA4 rearrangement } \\
\text { TERT promoter }-124 \mathrm{C}>\mathrm{T}\end{array}$ & Classical \\
\hline 6 & $\begin{array}{l}\text { Foundation Medicine } \\
\text { International } \\
\text { Cambridge, MA }\end{array}$ & $\begin{array}{l}\text { ATM } \\
\text { MAP2K1 } \\
\text { PDGFRA } \\
\text { PTEN } \\
\text { IRF2 }\end{array}$ & Proneural \\
\hline 7 & $\begin{array}{l}\text { Foundation Medicine } \\
\text { International } \\
\text { Cambridge, MA }\end{array}$ & BRAF V600E- alteration & Atypical \\
\hline
\end{tabular}

Possible responses to treatment included an OR, specifically, complete disappearance of gadolinium enhancement (CR) or $\geq 50 \%$ reduction in gadolinium enhancement (PR), i.e., SUM $\leq 50 \%$ of baseline SUM, and progressive disease (PD), which was evident when there was a $\geq 25 \%$ increase in gadolinium enhancement (i.e., SUM $\geq 25 \%$ of the baseline SUM or $\geq 25 \%$ of the smallest SUM achieved during treatment) or the appearance of new measureable lesions. The duration of each response was measured from the date that the response was first observed until the date that $\mathrm{PD}$ became evident.

Common Terminology Criteria for Adverse Events was used to document toxicities related to therapy.

\subsection{Treatment}

Based on genetic testing, five patients received a combination of, AS2-1, A10, BVZ, dasatinib, everolimus and pazopanib while one patient received AS2-1, ipilimumab and nivolumab, and one patient received AS2-1, BVZ, and PB. See Table 3. 
Table 3. Treatment received at BC

\begin{tabular}{|c|c|c|c|c|}
\hline Case \# & Age (yrs) & $\begin{array}{l}\text { KPS at } \\
\text { treatment start }\end{array}$ & Onset of targeted therapy & Days on treatment \\
\hline 1 & 47 & 90 & $\begin{array}{l}\text { 9/9/15 - pazopanib } \\
\text { 9/11/15 - ANP } \\
\text { 9/11/15 - dasatinib } \\
\text { 9/15/15 - BVZ } \\
\text { 9/17/15 - everolimus }\end{array}$ & 55 \\
\hline 2 & 57 & 80 & $\begin{array}{l}\text { 10/22/15 - ANP } \\
\text { 10/23/15 - everolimus } \\
\text { 10/23/15 - dasatinib } \\
\text { 10/27/15 - BVZ } \\
\text { 11/02/15 - pazopanib }\end{array}$ & 65 \\
\hline 3 & 39 & 50 & $\begin{array}{l}\text { 12/15/16 - AS2-1 } \\
12 / 20 / 16 \text { - BVZ } \\
\text { 12/20/16 - everolimus } \\
\text { 12/27/16 - pazopanib } \\
\text { 12/27/16 - dasatinib } \\
\text { 2/15/2017 - A10 }\end{array}$ & 119 \\
\hline 4 & 27 & 90 & $\begin{array}{l}2 / 15 / 17 \text { - AS2-1 } \\
\text { 2/16/17 - dasatinib } \\
2 / 20 / 17 \text { - everolimus } \\
\text { 2/22/17 - pazopanib } \\
2 / 27 / 17 \text { - BVZ }\end{array}$ & 181 \\
\hline 5 & 55 & 70 & $\begin{array}{l}\text { 3/27/2017 - AS2-1 } \\
\text { 3/28/17 - BVZ } \\
\text { 3/29/17 - pazopanib } \\
\text { 3/29/17 - everolimus } \\
\text { 4/4/17 - dasatinib }\end{array}$ & 101 \\
\hline 6 & 50 & 60 & $\begin{array}{l}\text { 7/13/17 AS2-1 } \\
\text { 7/18/17 - ipilimumab } \\
\text { 7/18/17 - nivolumab }\end{array}$ & 79 \\
\hline 7 & 23 & 90 & $\begin{array}{l}\text { 5/26/2016 - AS2-1 } \\
6 / 17 / 16-7 / 14 / 16 \text { - BVZ } \\
6 / 2 / 16-11 / 25 / 16 \text { PB }\end{array}$ & 208 \\
\hline
\end{tabular}

Abbreviations: ANP, antineoplaston therapy (AS2-1 + A10); BC, Burzynski Clinic; BVZ, bevacizumab; KPS, Karnofsky Performance Status; $\mathrm{PB}$, sodium phenylbutyrate

Antineoplastons AS2-1 and A10 were administered intravenously (IV) via a subclavian vein catheter (Hickman, Groshong, Broviac) and portable infusion pump as previously described (SR Burzynski, Janicki \& GS Burzynski, 2014). A single channel infusion pump was used for the administration of AS2-1 while a double channel infusion pump was used for the administration of AS2-1 and A10. BVZ $(10.0 \mathrm{mg} / \mathrm{kg})$ was infused IV every two weeks while everolimus (Afinitor), 2.5-5.0 mg, dasatinib (Sprycel), 20.0-50.0 mg, and pazopanib (Votrient), $200.0 \mathrm{mg}$, were administered orally, on a daily basis, at a $50 \%$ to $75 \%$ dose reduction. Ipilimumab (Yervoy), $1.0 \mathrm{mg} / \mathrm{kg}$, and nivolumab (Opdivo), $3 \mathrm{mg} / \mathrm{kg}$, were infused IV every three weeks.

\section{Results}

\subsection{Demographics}

Seven evaluable patients are the focus of this report. The demographics of these seven patients are shown in Table 4. 
Table 4. Demographics

\begin{tabular}{llllll}
\hline Age $(\mathrm{yrs})$ & \multicolumn{3}{l}{ Gender } & KPS & \\
\hline Median & Range & Male & Female & Median & Range \\
\hline 47 & $23.9-57.2$ & 5 & 2 & 80 & $50-90$ \\
\hline
\end{tabular}

Abbreviations: KPS, Karnofsky Performance Status

\subsection{Response and Survival}

An OR was achieved in six patients (85.7\%) with a CR (complete disappearance of gadolinium enhancement) being achieved in four patients $(57.1 \%$ ) and a PR, i.e., $\geq 50 \%$ reduction in gadolinium enhancement (SUM $\leq$ to $50 \%$ of baseline SUM) was achieved in two patients $(28.6 \%)$. PD, a $\geq 25 \%$ increase in gadolinium enhancement (i.e., SUM $\geq 25 \%$ of the baseline SUM or $\geq 25 \%$ of the smallest SUM achieved during treatment) or the appearance of new measureable lesions, was seen in one patient (14.3\%). The median time to first response was 29 days (range: 22-96 days) while the median duration of response was 141 days (range 55-739+ days). See Table 4.

Figure 1 shows Kaplan Meier survival curves for this group of patients. Six- and 12-months PFS was 57\% and $19 \%$, respectively, while 6- and 12 -month OS was $86 \%$ and $54 \%$, respectively.

\subsection{Safety and Adverse Events}

There were no grade 4 AEs while there were five grade 3 AEs, none of which were related to antineoplastons. Grade 1 or 2 AEs related to antineoplastons were fatigue (2 patients), polydipsia (1 patient), and paresthesia (1 patient).

\subsection{Case Studies}

\subsubsection{Case \#2 as listed in Tables 1-5}

In October 2011, this patient, a 57-year-old Caucasian male, experienced seizures. MRI showed a mass in the right parietal area and biopsy suggested a grade 3 oligoastrocytoma and gliomatosis. In November 2011, he underwent subtotal resection of an $8 \times 5.5 \mathrm{~cm}$ tumor that involved the right temporal, occipital and parietal lobes and the corpus callosum. Pathologic examination demonstrated a GBM. RT and TMZ were administered, but two weeks after completion of RT, the patient developed recurrent disease and subsequently underwent a second resection. Six weeks later he began treatment at BC (Table 1) where baseline MRI revealed a $5.2 \times 4.3 \mathrm{~cm}$ tumor. Following six weeks of treatment with PB, BVZ, erlotinib, sirolimus, and TMZ, the patient achieved a CR, which persisted for three and one-half years. In August 2015, MRI showed recurrent tumor in the right temporal and parietal lobes and the patient underwent another tumor resection with pathologic examination demonstrating rGBM. The patient returned to BC (Table 5) and received pazopanib, AS2-1, A10, dasatinib, BVZ, and everolimus. On this treatment, he achieved a CR (see Figure 2) with PFS of 9.4 months and OS (from the start of his second course of treatment at $\mathrm{BC}$ ) of 12.0 months. The patient's treatment was prematurely discontinued after eight weeks. 
Table 5. Results of AS2-1 plus targeted therapy received at BC

\begin{tabular}{|c|c|c|c|c|}
\hline Case \# & Best response & $\begin{array}{l}\text { MRIs: Baseline and follow-up } \\
\text { with response status }\end{array}$ & PFS (days) & $\begin{array}{l}\text { OS (days) and } \\
\text { patient status }\end{array}$ \\
\hline 1 & CR & $\begin{array}{l}9 / 1 / 15 \mathrm{BL} \\
10 / 5 / 15 \mathrm{CR} \\
11 / 2 / 15 \mathrm{CR} \\
2 / 1 / 16 \mathrm{CR} \\
5 / 10 / 16 \mathrm{CR} \\
7 / 5 / 16 \mathrm{PD}\end{array}$ & 298 & $\begin{array}{l}732+ \\
\text { alive }\end{array}$ \\
\hline 2 & $\mathrm{CR}$ & $\begin{array}{l}10 / 15 / 15 \mathrm{BL} \\
11 / 30 / 15 \\
1 / 4 / 16 \mathrm{CR} \\
4 / 15 / 16 \mathrm{CR} \\
8 / 4 / 16 \mathrm{PD}\end{array}$ & 287 & $\begin{array}{l}376 \\
\text { deceased }\end{array}$ \\
\hline 3 & PR & $\begin{array}{l}12 / 9 / 16 \mathrm{BL} \\
1 / 10 / 17 \mathrm{PR} \\
2 / 4 / 17 \mathrm{PR} \\
3 / 30 / 17 \mathrm{PR}\end{array}$ & --- & $\begin{array}{l}224+ \\
\text { alive }\end{array}$ \\
\hline 4 & CR & $\begin{array}{l}\text { 2/14/17 BL } \\
3 / 19 / 17 \mathrm{CR}^{*} \\
5 / 4 / 17 \mathrm{PD} \\
6 / 15 / 17 \mathrm{PD} \\
7 / 19 / 17 \mathrm{PD}\end{array}$ & 78 & $\begin{array}{l}211 \\
\text { deceased }\end{array}$ \\
\hline 5 & PR & $\begin{array}{l}\text { 3/1/17 BL } \\
3 / 28 / 17 \\
\text { 4/27/17 } \mathrm{PR}^{*} \\
6 / 1 / 17 \mathrm{PD}\end{array}$ & 66 & $\begin{array}{l}314 \\
\text { deceased }\end{array}$ \\
\hline 6 & PD & $\begin{array}{l}\text { 6/28/17 BL } \\
7 / 26 / 17 \mathrm{PD}\end{array}$ & 13 & $\begin{array}{l}120 \\
\text { deceased }\end{array}$ \\
\hline 7 & $\mathrm{CR}$ & $\begin{array}{l}5 / 24 / 16 \mathrm{BL} \\
8 / 30 / 16 \mathrm{CR} \\
12 / 9 / 16 \mathrm{CR} \\
2 / 22 / 17 \mathrm{CR} \\
6 / 1 / 17 \mathrm{CR} \\
6 / 30 / 17 \mathrm{CR} \\
8 / 11 / 17 \mathrm{CR} \\
12 / 20 / 17 \mathrm{CR} \\
5 / 29 / 18 \mathrm{CR}\end{array}$ & --- & $\begin{array}{l}739+ \\
\text { alive }\end{array}$ \\
\hline
\end{tabular}

* A second MRI was not performed for confirmation of the CR/PR.

Abbreviations: BC, Burzynski Clinic; BL, baseline; CR, complete response; OS, overall survival; PD, progressive disease; PFS, progression-free survival; PR, partial response 


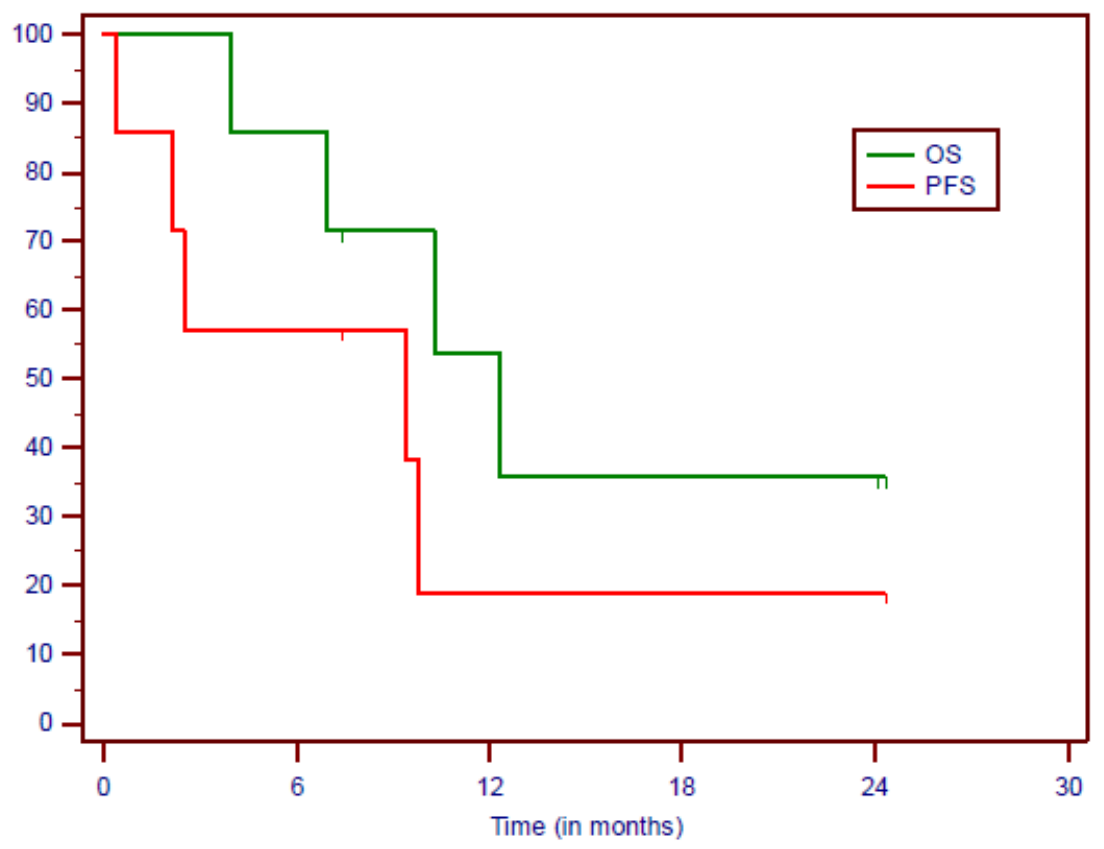

Figure 1. Kaplan Meier survival curves for study population

Abbreviations: OS, overall survival from treatment start; PFS, pro-gression-free survival from treatment start

\subsubsection{Case \#3 as listed in Tables 1-5}

This patient, a 39-year-old Caucasian male, underwent resection of a brain tumor in April 2014. Pathologic examination demonstrated a GBM. RT and TMZ were administered (Table 1), but he developed recurrent disease in August 2014 and underwent a second resection with pathologic examination demonstrating rGBM. The patient then received an experimental vaccine and additional TMZ. In September 2015, he developed PD and was treated with pembrolizumab and then nivolumab. Subsequently, he underwent a third, fourth, and fifth tumor resection. In December 2016, the patient began treatment at BC (Table 5) where he received AS2-1, BVZ, everolimus, pazopanib, dasatinib, and A10. On this treatment, he achieved a PR approximately one month after starting treatment (see Figure 3). From the start of his treatment at BC, OS was 7.3 months, but the patient prematurely discontinued his treatment three months after achieving a PR.

\section{Discussion}

No contemporary treatments for newly-diagnosed GBM or rGBM are curative. Photodynamic therapy following aggressive tumor resection (Kaneko et al., 2018), High-intensity focused ultrasound ablation (Alkins, et al., 2018), and nanotechnology-driven neuro-oncological interventions (Yoon, et al., 2018) may have impact on high grade gliomas.

However, an understanding of the molecular mechanisms and gene mutations involved in the development and growth of GBM are leading to more promising and tailored therapeutic approaches. Multiple challenges remain including tumor heterogeneity and rapid, aggressive tumor relapse. Therefore, the treatment of patients with newly-diagnosed GBM remains palliative and consists of maximal surgical resection, RT, and concomitant and adjuvant chemotherapy with TMZ (Stupp et al., 2005; Stupp et al., 2009). PFS and OS with TMZ is enhanced in patients with MGMT ( $\mathrm{O}^{6}$-methylguanine-DNA methyltransferase) promoter methylation (Hegi et al., 2004). 


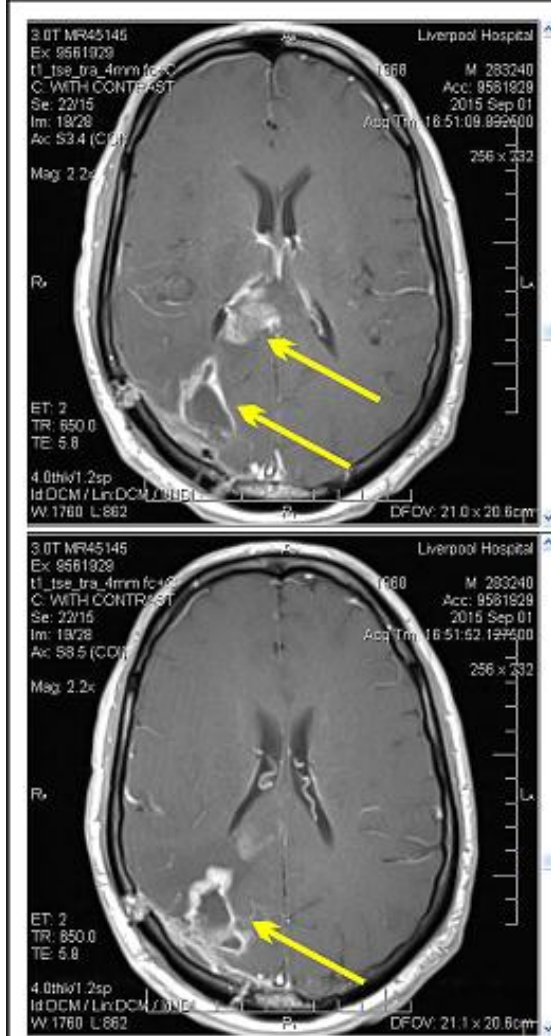

Baseline - Sep. 01, 2015

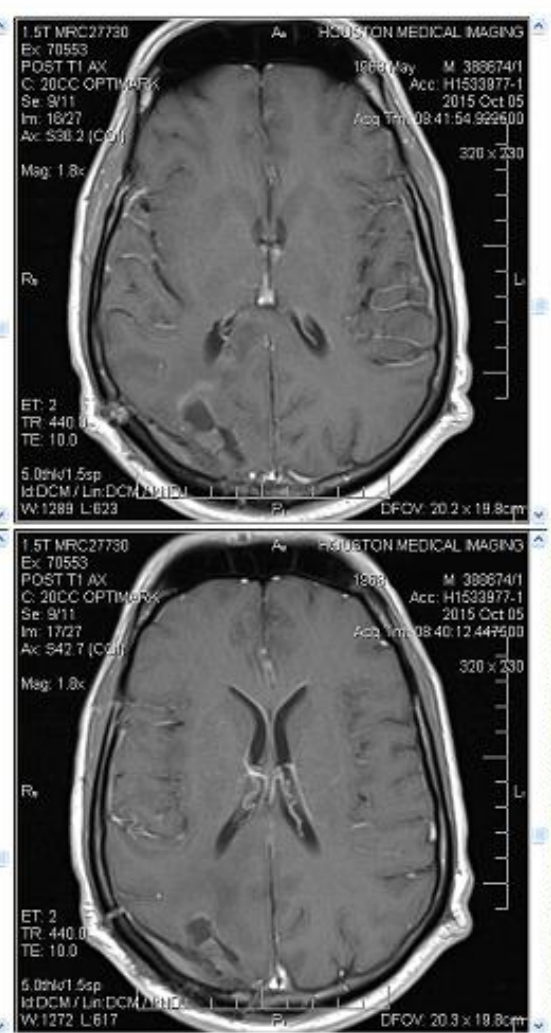

Follow-up - Oct. 05, 2015

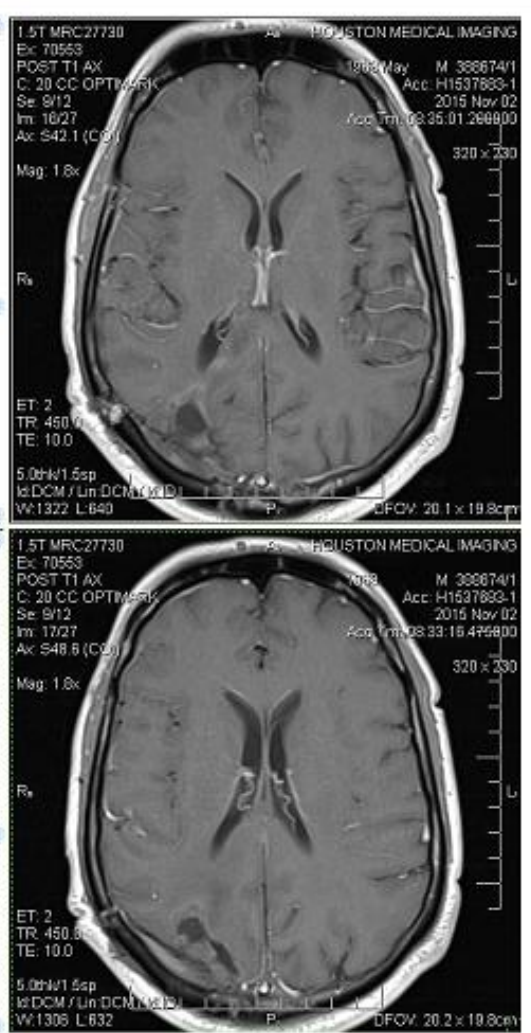

Follow-up - Nov. 02, 2015

Figure 2. MRI of the head in Case \#2. Post-gadolinium contrast T1 studies. Baseline - Sep. 01, 2015; Follow-up - Oct. 05, 2015 (first scan to show a CR); Follow-up - Nov. 02, 2015 (confirms the CR)

At BC, 29 rGBM patients were treated between 9/11/2015 and 06/23/2018. Seven had no prior treatment with bevacizumab elsewhere, had radiologic evidence of rGBM, and had MRI assessment of tumor response. These seven patients received AS2-1 and, based on genomic testing, also received targeted therapies that were given sequentially over a period of days as determined by the characteristics of the individual targeted therapies. Four of these seven patients achieved a CR while two patients achieved a PR.

E. Lee and colleagues reported on a multi-institutional study in which patients with recurrent high-grade glioma (HHG) were treated with oral panobinostat $30 \mathrm{mg}$ three times per week, every other week, in combination with BVZ $10 \mathrm{mg} / \mathrm{kg}$ every other week (Lee et al., 2015). The primary endpoint was 6-month PFS for patients with rGBM while patients with recurrent anaplastic glioma (AG) were evaluated as an exploratory arm of the study. Panobinostat is a histone deacetylase inhibitor with antineoplastic and antiangiogenic effects in glioma that may work synergistically with BVZ.

At interim analysis, the rGBM arm did not meet criteria for accrual (see Table 6). A total of 24 rGBM patients were accrued prior to study closure. The 6-month PFS was 30.4\%, median PFS was 5 months, and median OS was 9 months. The addition of panobinostat to BVZ in patients with rGBM did not improve 6-month PFS compared with historical controls of BVZ monotherapy. Our results show a better 6-month PFS (57\% vs 30.4\%), median PFS (9.4 vs 5 months), median OS (12.4 months vs 9 months) and CR (57\% vs 0). See Table 6. 

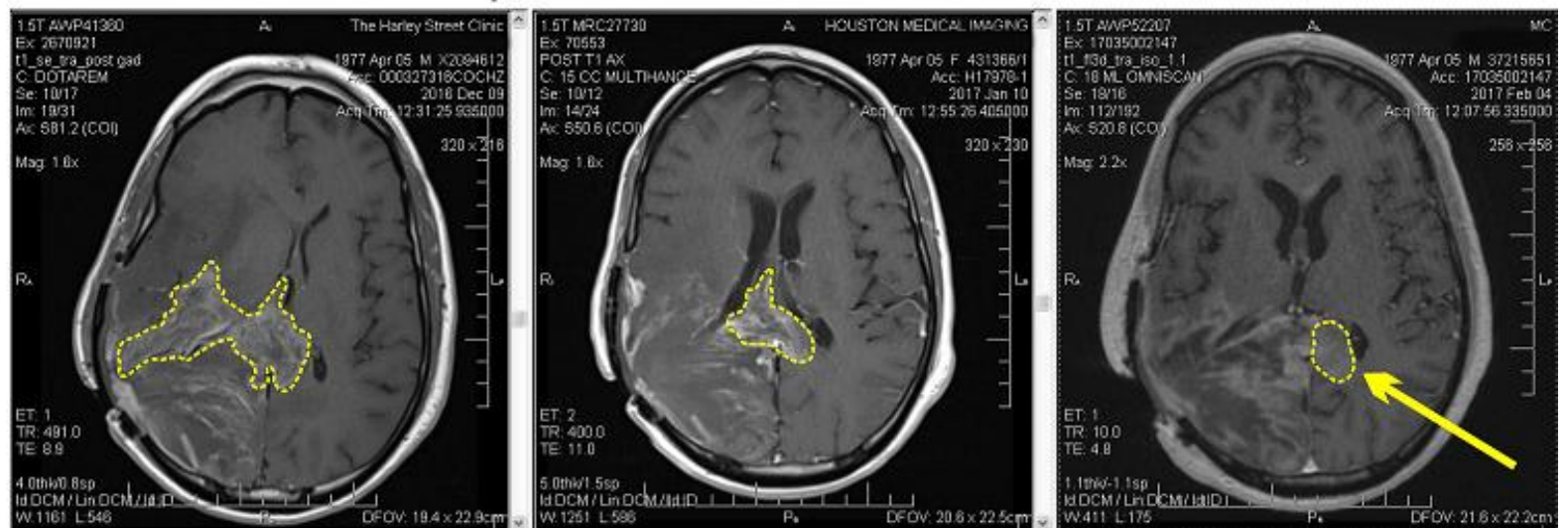

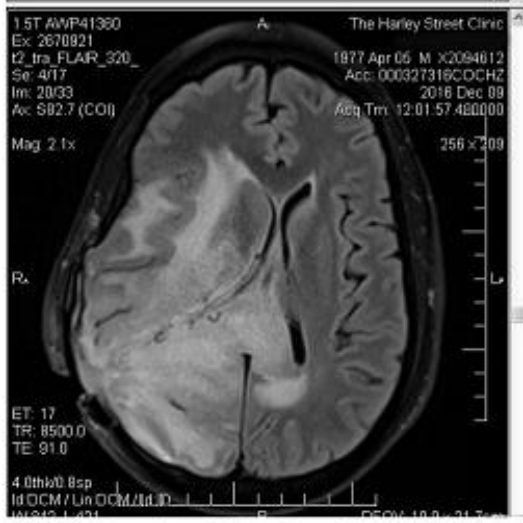

Baseline MRI - Dec. 09, 2016 Overall tumor size $9.9 \times 8.5=84.15 \mathrm{~cm}^{2}$ Solid enhancing portion $8.4 \times 5.3 \mathrm{~cm}=44.5 \mathrm{~cm}^{2}$

solid enhancement portion (active tumor)

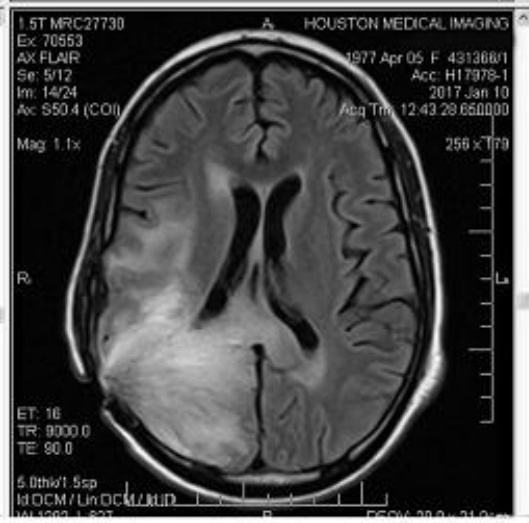

Follow-up MRI - Jan. 10, 2017

After 26 days of treatment

Overall tumor size $9.0 \times 7.5 \mathrm{~cm}=67.5 \mathrm{~cm}^{2}$

( $20 \%$ decrease)

Solid enhancing portion $4.0 \times 3.4 \mathrm{~cm}=13.6 \mathrm{~cm}^{2}$ ( $70 \%$ decrease)

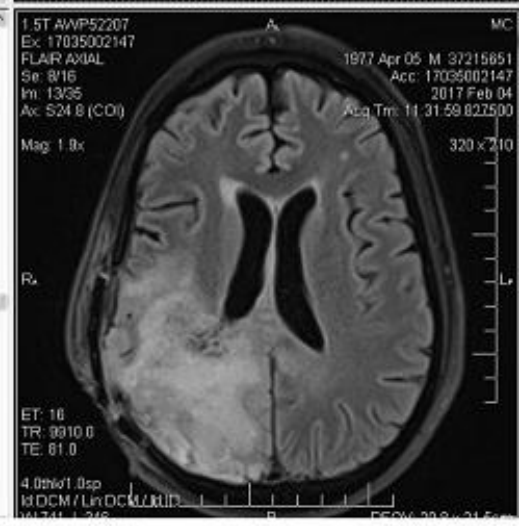

Follow-up MRI - Feb. 04, 2017 After 50 days of treatment

Overall tumor size $9.0 \times 7.5 \mathrm{~cm}=67.5 \mathrm{~cm}^{2}$

Solid enhancing portion $2.4 \times 1.6 \mathrm{~cm}=3.84 \mathrm{~cm}^{2}$ ( $91 \%$ decrease from baseline)

Figure 3. MRI of the head in Case \#3. Upper row shows post-gadolinium contrast T1 studies while lower row shows T2/FLAIR studies; Baseline - Dec. 09, 2016; Follow-up - Jan. 10, 2015 (first scan to show a PR);

Follow-up - Feb. 04, 2017 (confirms a PR)

J. Vredenburgh and colleagues reported on a phase II study of adults with recurrent grade II-IV glioma in which intravenous BVZ and irinotecan were given every two weeks of a six-week cycle (Vredenburgh et al., 2/2007). BVZ was administered at $10 \mathrm{mg} / \mathrm{kg}$ while the dose of irinotecan was determined based on the use of antiepileptics. Patients taking enzyme-inducing antiepileptic drugs received $340 \mathrm{mg} / \mathrm{m}^{2}$ while patients not taking enzyme-inducing antiepileptic drugs received $125 \mathrm{mg} / \mathrm{m}^{2}$.

Twenty-three patients with recurrent high-grade glioma in the phase II study were supplemented by a second cohort of 12 rGBM patients (Vredenburgh et al., 10/2007). This second cohort of patients received intravenous BVZ at $15 \mathrm{mg} / \mathrm{kg}$ every 21 days while irinotecan was administered on days 1, 8, 22, and 29 of a 42-day cycle at doses similar to those given to the first 23 patients. 
Table 6. Selected clinical studies in rGBM compared our study

\begin{tabular}{|c|c|c|c|}
\hline \multirow[t]{2}{*}{ Study } & Lee et al., 2015 & Vredenburgh et al., 10/2007 & \multirow{2}{*}{$\begin{array}{l}\text { Burzynski et al. } \\
\text { Retrospective analysis of } \\
\text { AS2-1 + targeted therapy in } \\
\text { rGBM November } 2018\end{array}$} \\
\hline & $\begin{array}{l}\text { Phase II panobinostat } \\
\text { with BVZ in rGBM and } \\
\text { AA (only rGBM data are } \\
\text { presented) January } 2015\end{array}$ & $\begin{array}{l}\text { BVZ and irinotecan in } \\
\text { rGBM October } 2007\end{array}$ & \\
\hline Treatment & $\begin{array}{l}\text { Oral panobinostat } 30 \mathrm{mg} \\
3 \mathrm{x} \text { per week, every other } \\
\text { week, in combination } \\
\text { with BVZ } 10 \mathrm{mg} / \mathrm{kg} \\
\text { every other week }\end{array}$ & $\begin{array}{l}\text { Two cohorts } \\
\text { 1. BVZ } 10 \quad \mathrm{mg} / \mathrm{kg}+ \\
\text { irinotecan every } 2 \text { weeks } \\
(\mathrm{n}=23) \\
\text { 2. BVZ } 15 \mathrm{mg} / \mathrm{kg} \text { every } 3 \\
\text { weeks }+ \text { irinotecan on days } \\
1,8,22,29(\mathrm{n}=12)\end{array}$ & $\begin{array}{l}\text { Three combinations } \\
\text { 1. ANP + pazopanib, dasatinib, } \\
\text { everolimus and BVZ }(n=5) \\
\text { 2. AS2-1 + ipilimumab and } \\
\text { nivolumab }(n=1) \\
\text { 3. AS2-1 + BVZ + PB }(n=1)\end{array}$ \\
\hline Primary end point & Six-month PFS & Six-month PFS & Retrospective analysis \\
\hline Exclusion & $\begin{array}{l}\text { Prior VEGF-targeted } \\
\text { therapies and/or HDAC } \\
\text { inhibitors, use of } \\
\text { anticonvulsants, use of } \\
\text { QT-prolonging drugs }\end{array}$ & Previous BVZ & BVZ given elsewhere. \\
\hline Age & $\geq 18$ & $\geq 18$ & $\geq 18$ \\
\hline KPS & $\geq 60$ & $\geq 60$ & $\geq 50$ \\
\hline \# of rGBM patients & 24 & 35 & 7 \\
\hline Six-month PFS & $30.4 \%$ & $46 \%$ & $57 \%$ \\
\hline $\begin{array}{l}\text { Median PFS } \\
\text { (months) }\end{array}$ & 5 & 5.5 & 9.4 \\
\hline Six-month OS & NA & $77 \%$ & $86 \%$ \\
\hline $\begin{array}{l}\text { Median OS } \\
\text { (months) }\end{array}$ & 9 & 15.5 & 12.4 \\
\hline Evaluation criteria & RANO & MacDonald & RANO \\
\hline MRI & Every 8 weeks & Every 6 weeks & Every 4-12 weeks \\
\hline $\mathrm{CR}$ & 0 & $6(17 \%)$ & $4(57 \%)$ \\
\hline PR & $7(29 \%)$ & $14(40 \%)$ & $2(29 \%)$ \\
\hline SD & $14(58 \%)$ & $15(43 \%)(\mathrm{SD}+\mathrm{PD})$ & --- \\
\hline PD & $3(13 \%)$ & $15(45 \%)(\mathrm{SD}+\mathrm{PD})$ & $1(14 \%)$ \\
\hline
\end{tabular}

Abbreviations: AA, anaplastic astrocytoma; ANP, antineoplaston therapy (AS2-1 + A10); BC, Burzynski Clinic; BVZ, bevacizumab; CR, complete response; HDAC, histone deacetylase; KPS, Karnofsky Performance Status; NA, not applicable; OS, overall survival; PB, sodium phenylbutyrate; PD, progressive disease; PFS, progression-free survival; PR, partial response; RANO, response assessment in neuro-oncology; rGBM, recurrent glioblastoma multiforme; SD, stable disease; VEGF, vascular endothelial growth factor

The 6-month PFS for the combined patient cohorts (n=35) was $46 \%$ while the 6-month OS was $77 \%$. Twenty of the 35 patients $(57 \%)$ had an objective tumor response. Based on these findings, there was no apparent difference in the efficacy of the therapeutic regimes utilized for the first and second cohorts of patients. Our results show a higher 6-month PFS (57\% vs 46\%), median PFS (9.4 vs 5.5 months), 6-month OS (86\% vs 77\%), CR (57\% vs $17 \%)$, but a lower PR (29\% vs 40\%) and median OS (12.4 vs 15.5 months). See Table 6.

For the seven rGBM patients reported here, an OR was achieved in $85.7 \%$. Six-month PFS was $57 \%$ and 6-month OS was $86 \%$. While only a general comparison can be made between results reported for the Lee and Vredenburg studies and our results, AS2-1 plus targeted therapy appears to provide for a better outcome in rGBM.

The duration of response at $\mathrm{BC}$ was negatively influenced by premature discontinuation of treatment based on patients' ill-advised decisions to stop treatment after achieving an OR. (Patients were responsible for the cost of targeted therapy.) It is known that GBM growth accelerates after discontinuation of BVZ.

We believe a phase II study is warranted. In keeping with the evidence presented in this report, patients will receive AS2-1 and targeted therapies given sequentially over a period of days. The mechanisms of action of AS2-1 and targeted therapy in GBM and rGBM have been described (Wick et al., 2011; Goel \& Mercurio, 2013; 
Prud'homme \& Glinka, 2012; Soker, Takashima, Miao, Neufeld \& Klagsbrun, 1998; Zachary, Frankel, Evans \& Pellet-Many, 2009; Kolodkin et al., 1997; Neufeld, Kessler \& Herzog, 2002; Nakayama \& Berger, 2013; Goel et al., 2012; Lu et al., 2012; Rizzolio et al., 2012; Grandclement et al., 2011; Ginka, Stoilova, Mohammed \& Prud'homme, 2011; West et al., 2005; Banerjee et al., 2006; Byzova et al., 2000; Wey et al., 2005; Staton et al., 2013; Beck et al., 2011; Snuderl et al., 2013; Ellis \& Hicklin, 2008; De Bacco et al., 2012; Bottsford-Miller, Coleman \& Sood, 2012).

In a phase II study of AS2-1 and targeted therapy, the number of patients enrolled will be based on the OR rate (see below). However, 6- and 12-month PFS and OS will be emphasized as endpoints because of the pseudoresponses that can be induced by BVZ. In addition, such a phase II study will be designed to allow a comparison of 1) AS2-1 plus targeted therapy for rGBM and 2) BVZ plus irinotecan for rGBM, especially the second Vredenburg study cited (Vredenburgh et al., 10/2007). Studies of BVZ and irinotecan have not proven their usefulness in the practice of neuro-oncology. It has been stated that the addition of irinotecan to BVZ has "failed to show any additional activity" (Lee, McFaline-Figueroa, Cloughesy \& Wen, 2018).

The phase II study envisioned would incorporate a strategy for early assessment of OR rates with procedures for termination of enrollment for lack of efficacy. An optimal two-stage design would be utilized (Simon, 1989). If the OR rate is $\geq 19 \%$, then this design allows for enrollment of sufficient patients to compare the OS and PFS in the phase II study of AS2-1 and targeted therapy to the OS and PFS in the second Vredenburg study sited (Vredenburgh et al., 10/2007).

\section{Conclusion}

There is no standard of care for rGBM. Clinical studies with single chemotherapy and targeted agents or their combination have shown some promise, but progress has been modest at best. Our report provides evidence that a high response rate in rGBM utilizing AS2-1 and targeted agents can be achieved. With appropriate dose reductions, we have shown that such treatment is well tolerated. These findings suggest that AS2-1 in combination with targeted agent carries significant promise for a rapid and durable response in rGBM with acceptable toxicity. Therefore, as described above, we propose a phase II study of AS2-1 plus targeted therapy in patients with rGBM following standard of care therapy.

\section{Acknowledgements}

The authors express their appreciation to Carolyn Powers for preparation of the manuscript and to Ramiro Rivera, Jennifer Pineda and Adam Golunski for their involvement.

\section{References}

Alkins, R. D., \& Mainprize, T. G. (2018) High-intensity focused ultrasound ablation therapy of gliomas. In: Chernov, M. F., Muragaki, Y., Kesari, S. \& McCutcheon I. E. (Eds). Intracranial gliomas. Part III Innovative treatment modalities. Progress in Neurological Surgery. Basel, Karger 32, 196-210. http://dx.doi.org/10.1159/000469678

Banerjee, S., Sengupta, K., Dhar, K., Mehta, S., D’Amore, P. A., Dhar, G., \& Banerjee, S. K. (2006). Breast Cancer Cells Secreted Platelet-Derived Growth Factor-Induced Motility of Vascular Smooth Muscle Cells in Mediated Through Neuropilin-1. Molecular Carcinogenesis, 45, 871-880. http://dx.doi.org/10.1002/mc.20248

Beck, B., Driessens, G., Goossens, S., Youssef, K. K., Kuchnio, A., Caauwe, A., ... Blanpain, C. (2011). A vascular niche and a VEGF-Nrp1 loop regular the initiation and stemness of skin tumours. Nature, 478, 399-403. https:// doi.org/10.1038/nature10525

Bottsford-Miller, J. N., Coleman, R. L., \& Sood, A. K. (2012). Resistance and escape from antiangiogenesis therapy: Clinical implications and future strategies. Journal of Clinical Oncology, 30, 4026-4034. http://dx.doi.org/10.1200/JCO.2012.41.9242

Burzynski, S. R. (1976). Antineoplastons: Biochemical defense against cancer. Physiological Chemistry and Physics, 8, 275-279.

Burzynski, S. R. (1986). Antineoplastons - History of the research (I). Drugs under Experimental Clinical Research, 12, 1-9.

Burzynski, S. R. (2004). The present state of antineoplaston research (1). Integrative Cancer Therapies, 3, 47-58. http://dx.doi.org/10.1177/1534735403261964

Burzynski, S. R. (2006). Treatments for astrocytic tumors in children: Current and emerging strategies. Pediatric 
Drugs, 8, 167-168. http://dx.doi.org/10.2165/00148581-200608030-00003

Burzynski, S. R., Burzynski, G. S., \& Janicki, T. J. (2014). Recurrent glioblastoma multiforme-A strategy for long-term survival. Journal of Cancer Therapy, 5, 957-976. http://dx.doi.org/10.4236/jct.2014.510101

Burzynski, S. R., Janicki, T. J., \& Burzynski, G. S. (2014). A phase II study of antineoplastons A10 and AS2-1 in adult patients with recurrent glioblastoma multiforme: Final report (Protocol BT-21). Journal of Cancer Therapy, 5, 946-956. http://dx.doi.org/10.4236/jct.2014.510100

Burzynski, S. R., Janicki, T. J., Burzynski, G. S., \& Marszalek, A. (2014). The response and survival of children with recurrent diffuse intrinsic pontine glioma based on phase II study of antineoplastons A10 and AS2-1 in patients with brainstem glioma. Childs Nervous System, 30, 2051-2061.

http://dx.doi.org/10.1007/s00381-014-2401-z

Burzynski, S. R., Janicki, T. J., Burzynski, G. S., \& Marszalek, A. (2014). A phase II study of antineoplastons A10 and AS2-1 in children with high-grade glioma. Final report (Protocol BT-06) and review of recent trials. Journal of Cancer Therapy, 5, 565-577. http://dx.doi.org/10.4236/jct.2014.56065

Burzynski, S. R., Janicki, T. J., Burzynski, G. S., Marszalek, A., \& Brookman, S. (2014). A phase II study of antineoplastons A10 and AS2-1 in children with recurrent, refractory or progressive primary brain tumors-Final report (Protocol BT-22). Journal of Cancer Therapy, 5, 977-988.

http://dx.doi.org/10.4236/jct.2014.510102

Burzynski, S. R., \& Patil, S. (2014). The effect of antineoplastons A10 and AS2-1 and metabolites of sodium phe- nylbutyrate on gene expression in glioblastoma multiforme. Journal of Cancer Therapy, 5, 929-945. http://dx.doi.org/10.4236/jct.2014.510099

Byzova, T. V., Goldman, C. K., Pampori, N., Thomas, K. A., Bett, A., Shattil, S. J. \& Plow, E. F. (2000). A mechanism for modulation of cellular responses to VEGF: Activation of the integrins. Molecular Cell, 6, 851-860. https://dx.doi.org/10.1016/S1097-2765(05)00076-6

De Bacco, F., Casanova, E., Medico, E., Pellegatta, S., Orzan, F., Albano, R., ... Boccaccio, C. (2012). The MET oncogene is a functional marker of a glioblastoma stem cell subtype. Cancer Research, 72, 4537-4550. http://dx.doi.org/10.1158/0008-5472.CAN-11-3490

Ellis, L. M. \& Hicklin, D. J. (2008). VEGF-targeted therapy: Mechanisms of anti-tumour activity. Nature Reviews Cancer, 8, 579-591. http://dx.doi.org/10.1038/nrc2403

Ginka, Y., Stoilova, S., Mohammed, N., \& Prud'homme, G.J. (2011). Neuropilin-1 exerts co-receptor function for TGF- $\beta-1$ on the membrane of cancer cells and enhances responses to both latent and active TGF- $\beta$. Carcinogenesis, 32, 613-621. http://dx.doi.org/10.1093/carcin/bgq281

Goel, H. L., Chang, C., Pursell, B., Leav, I., Lyle, S., Xi, H. S., .. Mercurio, A. M. (2012). VEGF/neurophilin-2 regulation of Bmi-1 and consequent repression of IGF-1R define a novel mechanism of aggressive prostate cancer. Cancer Discovery, 2, 906-921. http://dx.doi.org/10.1158/2159-8290.CD-12-0085

Goel H. L. \& Mercurio, A. M. (2013). VEGF targets the tumour cell. Nature Reviews Cancer, 13, 871-882. http://dx.doi.org/10.1038/nrc3627

Grandclement, C., Pallandre, J. R., Degano, S. V., Viel, E., Bouard, A., Balland, J., ... Borg, C. (2011). Neuropilin-2 expression mesenchymal transition in colorectal cancer cells. PLOS ONE, 6, Article ID: e20444. http://dx.doi.org/10.1371/journal.pone.0020444

Hegi, M. E., Diserens, A-C, Godard, S., Dietrich, P.-Y., Regli, L., Ostermann, S., ... Stupp, R. (2004). Clinical trial substantiates the predictive value of O-6-methylguanine-DNA methyltransferase promoter methylation in glioblastoma patients treated with temozolomide. Clinical Cancer Research, 10, 1871-1874. http://dx.doi.org/10.1158/1078-0432.CCR-03-0384

Kaneko, S., Fujimoto, S., Yamaguchi, H., Yamauchi, T., Yoshimoto, T., \& Tokuda, K. (2018). In: Chernov, M. F., Muragaki, Y., Kesari, S. \& McCutcheon I. E. (Eds). Intacranial gliomas. Part III - Innovative treatment modalities. Progress in Neurological Surgery. Basel, Karger 32, 196-210. http://dx.doi.org/10.1159/000469675

Kolodkin, A. L., Levengood, D. V., Rowe, E. G., Tai, Y. T., Giger, R. J. \& Ginty, D. D. (1997). Neuropilin is a semaphorin III receptor. Cell, 90, 735-762. http://dx.doi.org/10.1016/S0092-8674(00)80535-8

Lee, E. Q., McFaline-Figueroa, J. R., Cloughesy, T. F., \& Wen, P. Y. (2018). Is it time to reconsider the role of irinotecan for the treatment of high-grade gliomas?. Neuro-Oncology, 20, 1144. 
https://doi.org/10.1093/neuonc/noy092

Lee, E. Q., Reardon, D. A., Schiff, D., Drappatz, J., Muzikansky, A., Grimm, S. A., .. Wen, P. Y. (2015). Phase II study of panobinostat in combination with bevacizumab for recurrent glioblastoma and anaplastic glioma. Neuro-Oncology, 17(6), 862-867. https://doi.org/10.1093/neuonc/nou350

Lu, K. V., Chang, J. P., Parachoniak, C. A., Pandika, M. M., Aghi, M. K., Meyronet, D., ... Bergers, G. (2012). VEGF inhibits tumor cell invasion and mesenchymal transition through a MET/VEGFR2 complex. Cancer Cell, 22, 21-35. https://doi.org/10.1016/j.ccr.2012.05.037

Nakayama, M. \& Berger, P. (2013). Coordination of VEGF receptor trafficking and signaling by coreceptors. Experimental Cell Research, 319, 1340-1347. http://dx.doi.org/10.1016/j.yexcr.2013.03.008

Neufeld, G., Kessler, O. \& Herzog, Y. (2002). The interaction of neuropilin-1 and neuropilin-2 with tyrosine-kinase receptors for VEGF. Advances in Experimental Medicine and Biology, 515, 81-90. http://dx.doi.org/10.1007/978-1-4615-0119-0_7

Ohka, F., Natsume, A. \& Wakabayashi, T. (2012). Current trends in targeted therapies for glioblastoma multiforme. Neurology Research International. http://dx.doi.org/10.1155/2012/878425

Olson, J. J., Nayak, L., Ormond, D. R., Wen, P. Y., Kalkanis, S. N., \& Ryken, T. C. (2014). The role of targeted therapies in the management of progressive glioblastoma. Journal of Neuro-Oncology, 118, 557-599. http://dx.doi.org/10.1007/s11060-013-1339-4

Ostrom, Q. T., Gittleman, H., Truitt, G., Boscia, A., Kruchko, C., Barnholtz-Sloan, J. S. (2018). CBTRUS statistical report: Primary brain and other central nervous system tumors diagnosed in the United States in 2011-2015. Neuro-Oncology, 20, iv1-iv86. https://doi.org/10.1093/neuonc/noy131

Prud'homme, G. J., \& Glinka Y. (2012). Neuropilins are multifunctional coreceptors involved in tumor initiation, growth, metastasis and immunity. Oncotarget, 3, 921-939. https://dx.doi.org/10.18632/oncotarget.626

Rizzolio, S., Rabinowicz, N., Rainero, E., Lanzetti, L., Serini, G., Norman, J., ... Tamagnone, L. (2012). Neuropilin-1-dependent regulation of EGF-receptor signaling. Cancer Research, 72, 5801-5811. http://dx.doi.org/10.1158/0008-5472.CAN-12-0995

Simon R. (1989). Optimal two-stage designs for phase II clinical trials. Controlled Clinical Trials, 10, 1-10. https://doi.org/10.1016/0197-2456(89)90015-9

Snuderl, M., Batista, A., Kirkpatrick, N. D., de Almodovar, C. R., Riedemann, L., Walsh, E. C., ... Jain, R. K. (2013). Targeting placental growth factor/neuropilin 1 pathway inhibits growth and spread of medulloblastoma. Cell, 152, 1065-1076. http://dx.doi.org/10.1016/j.cell.2013.01.036

Soker, S., Takashima, S., Miao, H. Q., Neufeld, G. \& Klagsbrun, M. (1998) Neuropilin-1 is expressed by endothelial and tumor cells as an isoform-specific receptor for vascular endothelial growth factor. Cell, 92, 735-745. http://dx.doi.org/10.1016/S0092-8674(00)81402-6

Stanton, M. J., Dutta, S., Zhang, H., Polavaram, N. S., Leontovich, A. A., Honscheid, P., ... Datta, K. (2013). Autophagy control by the VEGF-C/NRP-2 axis in cancer and its implication for treatment resistance. Cancer Research, 73(1), 160-171. http://dx.doi.org/10.1158/0008-5472.CAN-11-3635

Stupp, R., Mason, W. P., van den Bent, M. J., Weller, M., Fisher, B., Taphoorn, M. J. B., ... Mirimanoff, R. O. (2005). Radiotherapy plus concomitant and adjuvant temozolomide for glioblastoma. New England Journal of Medicine, 352, 987-996. http://dx.doi.org/10.1056/NEJMoa043330

Stupp, R., Hegi, M. E., Mason, W. P., van den Bent, M. J., Taphoorn, M. J. B., Janzer, R. C., ... Mirimanoff, R.-O. (2009). Effects of radiotherapy with concomitant and adjuvant temozolomide versus radiotherapy alone on survival in glioblastoma in a randomised phase III study: 5-year analysis of the EORTC-NCIC trial. Lancet Oncology, 10(5), 459-466. http://dx.doi.org/10.1016/S1470-2045(09)70025-7

Vredenburgh J.J., Desjardins A., Herndon II J.E., et al (2/2007) Phase II trial of bevacizumab and irinotecan in recurrent malignant glioma. Clinical Cancer Research, 13, 1253-1259. https://dx.doi.org/10.1158/1078-0432.CCR-06-2309

Vredenburgh, J. J., Desjardins, A., Herndon, II J.E., et al (10/2007). Bevacizumab plus irinotecan in recurrent glioblastoma multiforme. Journal of Clinical Oncology, 25, 4722-4729.

https://dx.doi.org/10.1200/JCO.2007.12.2440

West, D. C., Rees, C. G., Duchesne, L., Patey, S. J., Terry, C. J., Turnbull, J. E., ... Fernig, D. G. (2005). 
Interactions of multiple heparin binding growth factors with neuropilin-1 and potentiation of the activity of fibroblast growth factor-2. The Journal of Biological Chemistry, 280, 13457-13464.

http://dx.doi.org/10.1074/jbc.M410924200

Wey, J. S., Gray, M. J., Fan, F., Belcheva, A., McCarty, M. F., Stoeltzing, O., ... Ellis, L. M. (2005). Overexpression of neuropilin-1 promotes constitutive MAPK signaling and chemoresistance in pancreatic cancer cells. British Journal of Cancer, 93, 233-241. http://dx.doi.org/10.1038/sj.bjc.6602663

Wick, W., Weller, M., Weiler, M., Batchelor, T., Yung, A. W. K. \& Platten, M. (2011). Pathway inhibition: emerging molecular targets for treating glioblastoma. Neuro-Oncology, 13(6), 566-579. http://dx.doi.org/10.1093/neuonc/nor039

Yoon, J. W., Jiang, W., Rutka, J. T., Huang, Y. \& Kim, B. Y. S. (2018) Perspectives of nanotechnology in the management of gliomas. In: Chernov, M. F., Muragaki, Y., Kesari, S. \& McCutcheon I. E. (Eds): Intacranial gliomas. Part III - Innovative treatment modalities. Progress in Neurological Surgery. Basel, Karger 32, 196-210. http://dx.doi.org/10.1159/000469691

Zachary, I. C., Frankel, P., Evans, I. M. \& Pellet-Many, C. (2009). The role of neuropilins in cell signalling. Biochemical Society Transactions, 37(6), 1171-1178. http://dx.doi.org/10.1042/BST0371171

\section{Copyrights}

Copyright for this article is retained by the author(s), with first publication rights granted to the journal.

This is an open-access article distributed under the terms and conditions of the Creative Commons Attribution license (http://creativecommons.org/licenses/by/4.0/). 